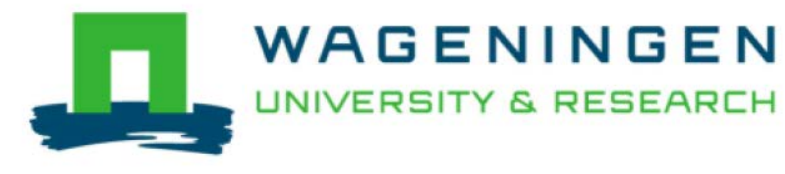

\title{
Private governance of ocean resources
}

\author{
Rolf A. Groeneveld, Simon R. Bush and Megan Bailey
}

This is a draft chapter. The final version is available in: Nunes, P.A.L.D.; Svensson, L.E. and Markandya, A. (Eds) 'Handbook on the Economics and Management for Sustainable Oceans' (2017) by Edward Elgar Publishing Ltd. The material cannot be used for any other purpose without further permission of the publisher, and is for private use only.

This version is distributed under a non-commencial no derivatives Creative Commons (c) $\& \Theta$ (CC-BY-NC-ND) user license, which permits use, distribution, and reproduction in any medium, provided the original work is properly cited and not used for commercial purposes. Further, the restriction applies that if you remix, transform, or build upon the material, you may not distribute the modified material.

Please cite this publication as follows:

Groeneveld, R.; Bush, S.R.; and Bailey, M. (2017) Private governance of ocean resources. In: Nunes, P.A.L.D.; Svensson, L.E. and Markandya, A. (Eds.) Handbook on the Economics and Management for Sustainable Oceans. pp. 416-428 (UN Environmental Programme and Edward Elgar Publishing House) http://dx.doi.org/10.4337/9781786430724.00031

You can access the published version at:

http://dx.doi.org/10.4337/9781786430724.00031 


\title{
Private governance of ocean resources
}

\author{
Rolf A. Groeneveld, Simon R. Bush and Megan Bailey
}

\section{Introduction}

The United Nations (UN) post-2015 development agenda (United Nations 2015) calls for the establishment of a global partnership for sustainable development, 'bringing together Governments, civil society, the private sector, the United Nations system and other actors and mobilizing all available resources’ (Art. 39). The agenda thereby explicitly acknowledges that in addition to governments, private companies and civil society have a pivotal role to play in attaining the new Sustainable Development Goals (SDGs).

The natural resource economics literature has traditionally applied a strict dichotomy between public actors (that is, governments) and private institutions, notably markets: markets take care of the allocation of private goods and services, while governments uphold the legal framework within which markets operate and correct market failures such as public goods, monopolies, and limited excludability of natural resources (see, for example, Perman et al. 2011; Tietenberg and Lewis 2012). The task of managing ocean resources has thus in recent history fallen squarely on the shoulders of the nation state. However, we have seen for complex systems, such as fisheries and marine ecosystems, that this dichotomy does not always hold (Ostrom 2010). Rather, the work of Ostrom and others (for example, Folke et al. 2005; Galaz et al. 2012) points to what is referred to as polycentric governance, where private and community institutional structures, sometimes integrated with and sometimes separate from the state, are offering new solutions to global governance challenges. These developments 
are blurring the strict separation of responsibilities between states, companies and, to an increasing extent, civil society.

For oceans, a range of sustainability governance arrangements have emerged in the last decade that sees new kinds of interaction between public and private actors. These interactions have arisen, in part, from the realization that oceans governance involves more than just management. Instead it requires diverse and effective institutions and is connected to ideas of values and principles (Symes 2006). Prominent examples of such initiatives are fisheries certification and seafood recommendation lists, where consumers are informed on sustainability aspects of fisheries and aquaculture products, and traceability schemes, where consumers can obtain detailed information on how and where their fish was caught (for example, Parkes et al. 2010; Bailey et al. 2016b). Moreover, rather than being strictly commercial or idealist, these sustainability initiatives are often the result of cooperation between private companies and civil society. For example, one of the most prolific fisheries certification programmes, the Marine Stewardship Council (MSC), was formed through a partnership between the World Wide Fund for Nature (WWF) and Unilever. However, observing that these initiatives exist does not explain why these interactions develop, what kinds of interactions they entail, or the extent to which decision-making control shifts back and forth between public and private actors and institutions.

In this chapter, we explore the rise of private sustainability initiatives in governing the oceans, evaluate the consequences of this movement and speculate on what it means for the future of state governance at both national and international levels. We do this by first describing three different private initiatives. Two of these, fisheries eco-certification and traceability schemes, are more commonly identified. The third, 
entrepreneurial marine protected areas (EMPAs), has received relatively little attention. We then synthesize these cases and reflect on their implication for the role of private companies, civil society and consumers in ocean governance.

\section{Fisheries certification}

Sustainability certification is perceived as a market-based governance arrangement that verifies compliance with normative standards that allow firms to advocate, steer and claim value over improved sustainability performance in the market. Certification is increasingly prominent across a broad range of sectors related to the marine environment, including the MSC for fisheries, the Aquaculture Stewardship Council (ASC) for aquaculture, and Blue Flag certification for beach and marina tourism (see, for example, Parkes et al. 2010; McKenna et al. 2011). Certification incorporates the setting of standards for ecological and social interactions, the auditing systems that measure compliance against these standards, attaching labels to products and enterprises which meet the standards, and creating institutions to coordinate these various functions (Hatanaka et al. 2005). While these functions are increasingly being coordinated by private organizations, such as firms and non-governmental organizations (NGOs), they also involve states in a number of ways.

Sustainability certification is generally believed to have emerged under two very different narratives related to state regulation. The first narrative is that certification has emerged in response to the difficulties that states, in particular in developing countries, have had in effectively regulating public marine resources such as fisheries. By setting 'higher' standards than state legislation, NGO-led certification is argued to incentivize governments to 'ratchet up’ their regulatory performance (Cashore et al. 2007). The 
second narrative argues that certification has emerged in response to over-regulation by states. By capping standards at an agreed minimum, industry seeks to avoid an inflation of the requirements for production. One noted consequence of this strategy is a so-called race-to-the-bottom, as firms bargain what constitutes minimum performance (Nadvi and Wältring 2002). However, while examples of these processes have been documented for fisheries and aquaculture (see, for example, Béné 2005), the interaction between certification is increasingly complex, with multiple forms of interactions and with different kinds of regulatory outcomes at both the national and international levels.

The interaction of certification with states is increasingly observed as a dynamic process of interaction, learning and improvement. For example, the implementation of MSC certification has resulted in a range of outcomes related to state involvement. As a variety of examples have demonstrated, states are clients, assessors, data providers and facilitators of certification (Ponte 2008; Foley 2013; Foley and Hébert 2013). Seen as such, states are far from 'standard takers', and instead contribute fundamentally to how private certification is assembled and operates (Gale and Haward 2011). However, a counter-movement is also observed, where states are opposing private standards by developing their national standards in response to concerns over cost and sovereignty. For example, Iceland and the US state of Alaska have both developed a state-based standard - the first for cod and the latter for salmon fisheries - in direct response and opposition to what they see as unnecessary costs associated with MSC assessment and marketing (Gulbrandsen 2009; Foley and Hébert 2013). Developing countries are also creating national standards, but unlike Iceland and the US these efforts are motivated by concerns that segments of their fishing and aquaculture industries are unable to comply with the international standards, and as such be excluded from the market. For example, 
in Thailand the government has developed the government-run and certified Thai Shrimp Label, while other governments in Southeast Asia have invested in Better Management Practice (BMP) and/or Good Aquaculture Practice (GAP) standards (Vandergeest 2007; Ha and Bush 2010). Both of these schemes are more inclusive of small-holders than the international schemes, but they are also constrained by a lack of recognition in export markets. Moreover, as noted by Vandergeest and Unno (2012), the standards imposed on fisheries and environmental policy by international certification bodies (often based in developed countries) have resonated with notions of an extension of extra-sovereign control.

At the international level, states are also closely implicated in private certification. First, there are examples of states coming together in different regional treaties and configurations to act as clients for MSC certification. The recent Parties to the Nauru Agreement (PNA) certification of transboundary purse seine fisheries targeting skipjack tuna without the use of fish aggregation devices (FADs) is a case in point. Here the PNA states have applied as the client for MSC certification in a publicprivate partnership with a Dutch-based company to market fish under the Pacifical brand (Moody Marine Limited 2011; Adolf et al. 2016). In doing so the PNA sought to strengthen the credibility and authority of transboundary conservation and management measures that, although now well established, were controversial and resisted at the broader regional fisheries management organization (RFMO) level (see Miller et al. 2014), as well as to regain a degree of normative and therefore sovereign control over the fishery from the distant water fleets subject to MSC compliance. Second, the MSC has in always sought strong state oversight for their own legitimacy from intergovernmental organizations. The first draft of the MSC standards were explicitly 
linked to a range of international agreements, including the United Nations Agreement on Highly Migratory Stocks and the Food and Agricultural Organization (FAO) Code of Conduct for Responsible Fisheries. From its inception the MSC has therefore drawn on the legitimacy of these intergovernmental institutions for their legitimacy and authority (Tamm Hallström and Boström 2010; Foley 2012). Perhaps somewhat ironically, these same intergovernmental institutions are now being used by private firms, notably supermarkets, to set new benchmarking or 'meta-standards' over the MSC and other fisheries and aquaculture standards under the Global Sustainable Seafood Initiative. Not only does this create a continued counter-movement against the MSC, it further blurs the boundaries of where and how public and private rules, legitimacy and authority play out in sustainability certification.

\section{Traceability}

Traceability, the structured transfer of information in value chains (Coff et al. 2008), has emerged as a way of addressing food safety risks, as well as the weak transparency of fisheries sustainability in many parts of the world. Traceability is not the information itself, but rather the system or tool that makes the flow of this information possible and allows for records of production and product movement to be accessible at a future date and at distant places (Donnelly and Olsen 2012). Traceability originated as a business management tool, where information flowed internally between supply chain actors, and supply chain efficiencies helped incentivize its early adoption (Caswell 1998). Once a voluntary process, basic traceability is now a requirement in most export-oriented seafood value chains purely for health and safety reasons, and while traceability originally focused on product attributes alone, the demand for sustainability information 
about the production process, especially by consumers and buyers, has required an evolution of these systems. Thus a new form of next generation traceability, which is voluntary and initiated by private actors, has taken off in recent years.

Consumer-facing traceability (CFT) includes the flow of information to consumers or civil society directly from value-chain actors, and is known as a form of transparency through disclosure, or informational governance (Mol 2015; Bailey et al. 2016a). Determining seafood product characteristics such as quality, origin and sustainability, known as credence attributes, can be almost impossible for buyers without some help (Wessels 2002). In many ways traceability has emerged largely in response to NGO-driven informational demands related to these intangible product characteristics and qualities (Jacquet et al. 2010). Consumer-facing traceability can serve as a platform that connects consumers directly with the source of, and information about, their seafood. However, the term CFT is presently all-encompassing but many systems have varying degrees of ‘faceability’ (Miller 2014). Some systems are developed by vertically integrated companies that display static information, and are based on proprietary databases. Other systems are outsourced to traceability providers and are used by both retailers and processors to organize seafood traceability (Fiorillo 2014). A final group of systems provide dynamic non-proprietary information and allow for direct two-way communication between fishers and consumers. While all of these systems are consumer-facing, 'the detail of and access to information differs, and as such, so does the degree of transparency they offer to consumers’ (Bailey et al. 2016a, p 28). Further to this, verification of claims made has not evolved to the same extent as it has in certification schemes, for example, those discussed above. Consumer-facing 
traceability thus has the potential to steer consumption towards traceable items, but offers no guarantees that the information it provides is correct.

Yet while it is led by civil society actors, and operationalized by private industry actors, traceability is also a system of interest to states, and a system that can strengthen state governance. The US and the European Union (EU) are particularly focused on promoting traceability as a method of combatting illegal, unreported and unregulated fishing (IUU). Here, traceability for regulatory purposes (Coff et al. 2008) becomes a means of validating product origin and species for exporting and importing countries with information flowing from value-chain actors to governments or regulators. Furthermore, it can be a tool to combat seafood mislabelling and fraud (Jacquet and Pauly 2008), which can be costly to the public and to private firms. State leadership in the design of these types of traceability systems, and the information these systems contain, will likely be necessary. However, unilateral state interventions, for example traceability requirements demanded by the US, are likely to cause unnecessary informational and capacity burdens on many seafood-exporting countries (Bailey et al. 2016a). Rather, multi-lateral public-private partnerships may be required to effectively harness the potential that traceability may have in governing ocean sustainability.

\section{Entrepreneurial Marine Protected Areas}

The involvement of private actors in the establishment of marine protected areas has steadily increased in recent decades as the need for sustainable funding models for conservation has become apparent (Christie and White 2007). In these so-called ‘entrepreneurial marine protected areas’ (EMPAs) (Colwell 1997), private actors seek business opportunities that fund a combination of conservation activities as well as the 
livelihoods of local resource users (Colwell 1998; de Groot and Bush 2010; Bottema and Bush 2012). The activities of these private entrepreneurs range from collecting diver fees to fund park management (Dixon et al. 1993; Tongson and Dygico 2004; de Groot and Bush 2010), to the design and implementation of co-management arrangements in state designated parks (Teh et al. 2008), and to varying degrees of private tenure over spatially delimited marine habitat (Svensson et al. 2010). However, while the number of these EMPAs has increased, the extent to which they can successfully implement area-based conservation measures depends in large part on legal recognition from the state.

The initial ambition of EMPAs was to stimulate the expansion of state-led marine protected areas (MPAs) in tropical developing countries, where establishment has generally been slow and/or dysfunctional. Colwell’s (1997, p. 110) initial description involved networks of small-scale protected areas managed by partnerships between local communities and private operators which 'have a vested economic interest in promoting abundant marine life'. He further indicated that these small areas might be developed within or in combination with state-led MPAs, but bring with them the added benefit of protecting discrete pockets of habitat. The role of private actors in these EMPAs is variously characterized as: a short-term intervention that raises local awareness and builds capacity towards the development of state-led protected areas (Colwell 1998); a way of providing alternative income to communities in and around these areas, and by doing so reducing extractive pressure on marine resources (Dixon et al. 1993; Christie and White 2007); and/or a source of long-term funding for conservation activities (Bottema and Bush 2012). 
The areal basis of EMPAs inevitably requires some degree of enclosure of public resources. Opportunities for private actors (the so-called 'entrepreneurs') are therefore dependent on support or changes to politics, policy and/or regulation from local to national levels. They are also dependent on their ability to successfully generate both individual and communal benefits, ensuring that local communities, as well as state actors, see both conservation and well-being at least maintained, and preferably increased (see Bush et al. 2017). The capacity of EMPAs to provide long-term solutions for marine conservation is therefore dependent on their capacity to deliver these benefits, which in turn influences the overall legitimacy in the eyes of both community and state actors. Because the authority of EMPAs is based on concessions or lease-hold arrangements over coastal habitat, they also remain dependent on community and state actors for cooperation around the compliance and enforcement of exclusion-related conservation rules. Even where state support is highly institutionalized, the durability of the EMPAs is subject to changes in national level support for private marine tenure. In some cases leases remain vulnerable to political change (for example, Riedmiller and Carter 2001) and in other cases local-level authority may shift to higher or lower levels of government (for example, Midavaine 2014), with different priorities than those that initially granted legitimacy and authority. Private control over marine conservation is therefore dependent on the state, given that it is the state that provides the institutional space for entrepreneurs to exploit and consolidate opportunities, while also ensuring they are able to contribute to the stewardship of public habitat and resources. Without a clear framework for state collaboration and support these private sustainability entrepreneurs are unlikely to be able to establish EMPAs as spatially delimited institutions around the conservation of marine resources over the long term. 
There is also a global ambition to establish a network of MPAs, covering 10 per cent of the world's oceans by 2020 (see Rife et al. 2013), as set out by the Convention on Biodiversity. The vision for achieving this target is based on a global network of MPAs spread across a range of habitats. But echoing the same critiques levelled at national-level MPAs, progress has been slow, funding inadequate and regulatory control weak (for example, Kearney et al. 2013; Roff 2014; White et al. 2014). It is enticing to consider whether EMPAs could contribute to this global network, but two major barriers stand in the way. First, EMPAs are dependent to a large extent on the kinds of local institutional dynamics outlined above, making any globally coherent strategy dependent on the same states that have not pushed the current CBD goal forward. Second, EMPAs appear to be a very 'national' solution, because it appears unlikely that there is a business case for private intervention in areas beyond national jurisdiction far from consumers (that is, tourists). As variously argued (for example, Mascia et al. 2010; Selig and Bruno 2010; Chuenpagdee et al. 2013), meeting the national and global demands for MPA establishment remains firmly linked to the local contexts within which conservation activities are embedded.

\section{Understanding public-private sustainability governance}

The consensus among economists is that government intervention is warranted, among others, in the presence of market failures (see, for example, Perman et al. 2011). These failures include, but are not limited to, externalities and public goods. Marine resources can in many ways be considered a common pool resource, and in this respect the emergence of private governance, where private parties contribute to the provision of the common good, may seem puzzling. Looking more closely at the cases discussed, 
however, three key insights emerge that help us to understand this development: (1) ocean governance is not only a public good, but also a marketable product attribute, especially in international markets; (2) ocean governance is increasingly about sustainability partnerships that complement the abilities of markets and governments; and (3) private governance should not be seen as supplanting state governance of marine resources, but rather as a complementary movement that can help strengthen states. We discuss these insights below.

\section{Ocean Governance as a Product Attribute}

The limitation of states to either effectively oversee and regulate the marine environment, or contribute regulation that supports the common good, opens up opportunities for private actors and governance mechanisms in the marine environment. In many ways, private governance has emerged during a time of increased individualism within society. The citizen-consumer is now being counted on to exercise his or her citizenry (Iles 2004) and to change the infrastructures of consumption (van den Burg et al. 2003). So private governance links with an increasing sense of individual responsibility in a time of increasing information availability. Such individualism is evident in all three cases. Certification is seen as a form of ethical or political consumerism, consumer traceability assumes a similar demand for knowing where and how fish are caught or produced, and EMPAs are driven by an assumption of funding from ethical tourism.

Peattie (2010) discusses 13 different factors that are thought to influence 'green' consumption, such as economic rationality, environmental knowledge and social norms. Drawing from these factors we can distinguish three broad types of motivation for 
consumers to consume 'green' products, such as certified or traceable goods: (1) the good's instrumental value to the consumer; (2) social motivations pertaining to the relation between the consumer and his or her peers; and (3) ethical motivations to 'do the right thing'. The instrumental value can include qualities such as taste or food safety; we might argue that consumers also get a 'warm glow' from buying a product labelled as environmentally friendly (see, for example, Hartmann and Apaolaza-Ibáñez 2012), although such considerations would be difficult to separate from sincerely moral considerations. Social motivations include such motivations as conforming to a social norm ('this is common practice') and identifying with a lifestyle that includes consumption of the 'green' product (or refusal to consume the 'non-green' variety). Finally, ethical motivations regard the intrinsically moral considerations when buying a product, that is, the consumer's own ethical norms and values, as well as the consumer's sense of responsibility for the ecological and environmental issues related to the 'green' (or in the marine case 'blue') good.

Responsibility is also taken on by firms, which through their corporate social responsibility (CSR) branches are becoming increasingly engaged in promoting and directing the sustainability agenda (Barin Cruz and Boehe 2008). For example, Bansal and Roth (2000) distinguish three types of motivations for firms to adopt CSR: (1) competitiveness, referring to the potential for CSR to improve long-term profitability; (2) legitimation, relating to the potential for CSR to improve a firm's compliance with prevailing social and legal norms; and (3) responsibility, relating to a firm’s concern with its own social obligations and values. Corporate social responsibility can improve a firm’s long-term profitability by adopting a more proactive policy towards social and environmental regulation (Carroll and Shabana 2010), or by developing niche markets 
for socially responsible products. Corporate social responsibility can also enhance a firm’s 'licence to operate’, that is, its reputation among consumers, employees and, ultimately, voters and policy-makers. Finally, CSR can reflect a firm’s intrinsic values associated with their use of the (marine) environment, or promoting their own values in the practices of those purchasing their products - be it direct consumption of fish or experiences through marine tourism.

The three types of motivations identified by Bansal and Roth (2000) mirror the types of motivations for consumers as explained above, and can be characterized as instrumental motivations (reflecting the instrumental value of a good or initiative to the individual firm or consumer), social motivations (reflecting the value of a good or initiative in the relation between the firm or consumer and others) and ethical motivations (reflecting the value of a good or initiative as an expression of a firm or a consumer's intrinsic moral values). A comparison of the three cases also shows there are concerns about the role of private actors in ocean governance. These concerns largely relate to the privatization of public concerns, and the erosion of state sovereignty. Regarding the first concern, Konefal (2013) argues that prioritizing the market and private actors can mean a select group of powerful individuals or firms (for example a company chief executive officer or a large corporation) has the power to decide what sustainability is, as opposed to allowing society more generally to make that decision. Similarly, others have been critical of the fact that the sustainability goals, and ways to approach those goals, should not be the responsibility of individuals, but rather the responsibility of public policy, in part because consumers can find navigating the sustainable consumption landscape confusing (Jacquet et al. 2010). This is all the more relevant when considering the consumer demand for any given environmental or 
social value associated product - be it a certified fish or ethical resort conserving coastal habitat - outside markets that currently exhibit demand for sustainable 'products' (see, for example, Bush et al. 2013). However, as we go on to discuss, aligning private governance approaches to individual behaviour in a market overlooks a range of organizational outcomes that emerge through public-private interaction.

\section{Ocean Governance as Sustainability Partnerships}

Closely related to the kinds of public-private interaction evident in the marine environment is the emergence of sustainability partnerships. Going further than simply the interaction between states and private actors, partnerships indicate the increasingly blurred relations that exist between governments, firms and civil society actors. Sustainability partnerships work on the principle of combining the market-based power of lead firms with the legitimacy of states to regulate marine resources (Vellema and van Wijk 2015). By partnering with firms, states can better coordinate the implementation of both voluntary and legislated sustainability measures, and in doing so increase their influence over production and trade, as well as the sustainability of fishery resources (Adolf et al. 2016). However, the three cases outlined above indicate that the extent of this influence is limited to private initiatives that are directed towards international markets. For instance, by establishing de facto conditions for export market access, certification places stringent requirements on firms and states to comply with sustainability standards. If states and firms act alone to comply with these standards they incur increased costs and a higher risk of non-compliance. However, if partnerships are formed, then they have a higher chance of compliance and strengthening their position in the market. Similarly, as international requirements for 
traceability increase in response to IUU regulation (as well as emerging issues of human trafficking), states and firms acting alone will be challenged in a similar way. While direct partnerships between companies and governments remain relatively rare in the marine environment (see, as exceptions, Bailey et al. 2016b; Adolf et al. 2016), there are a wide range of examples where civil society groups are providing a facilitative role in the development of sustainability partnerships, either by assisting the capacity of firms or states to meet legislative or voluntary market-based requirements, or by establishing dialogue between key actors to stimulate innovation in sustainability governance arrangements.

Despite the innovation surrounding these partnerships and their potential for new governance approaches, concerns have been raised. Returning to Konefal (2013), sustainability partnerships facilitated by apparently 'neutral' civil society have also reinforced control of companies over sustainability issues. In some cases these partnerships have been framed as being pre-competitive and providing an additional strategy to established private arrangements such as certification and traceability. Examples include industrial coalitions as seen in tuna fisheries with the International Seafood Sustainability Foundation (ISSF) and the Global Salmon Initiative (GSI) initiated in part by the WWF with major seafood companies. The result of this greater control remains unclear; it could result in considerable changes towards sustainability, but it may also enable firms to determine where and how they engage with sustainability improvements at timescales contrary to those initially intended. What this might point to is the need for a reinvigoration of these partnerships in new forms.

\section{Private Governance in Support of State Governance}


Despite the fact that the emergence of private actors in ocean governance can be explained by ideas around citizenship, consumer preference, CSR and sustainability partnerships, the governing potential of these mechanisms remains intimately tied to states. States are more often seeking private actors and governance mechanisms to supplement state regulation and control over ocean resources. In practice, this leads to a range of different potential interactions between states and private actors. As outlined by Gulbrandsen (2014), these interactions can range from complementary, where states benchmark and/or learn from more stringent private standards or rules, to mutually reinforcing the legitimacy of state legislation, to improved performance through greater transparency of state actions through private mechanisms. In the three cases outlined above, we can observe all three forms of interaction. Certification, for instance, plays multiple roles. By referring to and referencing state rules and regulations in its standards and auditing schedules, certification can reinforce both national and international state arrangements. In cases where standards are set above what is legislated, certification can also push states to change and innovate regulation.

Traceability can play a similar role to certification where states have weak or no traceability systems in place. By creating new systems of control in supply chains and setting new standards for how transparent the fishing industry should be, it can increase firm accountability towards reaching sustainability goals. However, perhaps the clearer interaction traceability can play is increasing the information available on food safety, as well as sustainability aspects related to how fish were caught, where, by who and in what quantities (Bailey et al. 2016b). In this way, traceability can help states to support their sustainability governance and procurement strategies. For example, in the US, the Presidential Task for on Combatting IUU Fishing and Seafood Fraud (NOAA 2015) 
includes traceability in a key set of recommendations. However, what is also apparent is that the information required by certification and traceability mechanisms is very complex. On one hand, the private actors involved in these two examples can be expected to have better access to market information; on the other hand, the information they provide to consumers on species and fisheries characteristics, such as stock status and fishing effort, depends heavily on efforts traditionally taken up by the state. So while private-actor innovation and leadership may have emerged from more individual motivations to develop, contribute to and purchase from certified and traceable fisheries, collective uptake and facilitation by the state is essential.

\section{Conclusion}

The past few decades have seen a shift in ocean governance from a predominant role for public actors (that is, states and intergovernmental organizations) to partnerships between governments and private actors, including firms, consumers and civil society. This shift is visible in the emergence of seafood certification, traceability and entrepreneurial MPAs, all of which are largely initiated by private firms in partnerships with civil society and governments. Besides the immediate profit motive to firms, considerations of reputation and corporate social responsibility cannot be ruled out as motivations for firms to engage in these activities.

Examples in northern Europe and Thailand, where seafood certification was met with opposition from governments, suggest an initial suspicion that private governance may hamper public governance. Recent developments, however, demonstrate that private governance can also enhance states’ authority and legitimacy. Despite the bigger role for private actors in certification, traceability and EMPAs, all three forms of private 
governance also depend heavily on the state, for example, as a provider of necessary information to certification and traceability, and as enforcer of private property rights of EMPAs. Private governance can also lend national governments greater legitimacy through an endorsement by international bodies, as demonstrated by the MSC certification of the PNA unassociated-sets tuna fishery.

Potentially, the private governance arrangements described in this chapter can contribute to the SDGs as formulated in the post-2015 Development Agenda (United Nations 2015), particularly to the conservation and sustainable use of marine resources (Goal 14). The examples discussed in this chapter demonstrate that certification of sustainable fishery practices has drawn consumers' attention to issues of overfishing and unregulated fisheries (Goal 14.4); the specific case of the MSC certification of the PNA unassociated-sets tuna fishery suggests that small island developing states (SIDSs) might also benefit from the improved access to the market offered by certification (Goal 14.7). In a similar vein, traceability can help address illegal and unreported fishing (Goal 14.4), whereas EMPAs are a contribution to Goal 14.5 on the conservation of coastal and marine areas.

Nevertheless, a word of caution is warranted against depending on private initiatives to address what are, essentially, problems of coordination in open-access and common-property resources. Despite the added value of private governance, and the goodwill of those involved, it cannot guarantee that policy objectives in ocean and coastal management will be attained. An active role for governments will therefore remain warranted.

\section{References}


Adolf, S., S.R. Bush and S. Vellema (2016), 'Reinserting state agency in global value chains: the case of MSC certified skipjack tuna', Fisheries Research, 182 (October), 79-87.

Bailey, M., S.R. Bush, A. Miller and M. Kochen (2016a), 'The role of traceability in transforming seafood governance in the global South', Current Opinion in Environmental Sustainability, 18 (February), 25-32.

Bailey, M., A.M.M. Miller, S.R. Bush, P.A.M. van Zwieten and B. Wiryawan (2016b), 'Closing the incentive gap: the role of public and private actors in governing Indonesia’s tuna fisheries’, Journal of Environmental Policy \& Planning, 18 (2), $141-60$.

Bansal, P. and K. Roth (2000), 'Why companies go green: a model of ecological responsiveness', Academy of Management Journal, 43 (4), 717-36.

Barin Cruz, L. and D.M. Boehe (2008), 'CSR in the global marketplace: towards sustainable global value chains’, Management Decision, 46 (8), 1187-209.

Béné, C. (2005), 'The good, the bad and the ugly’, Development Policy Review, 23 (5), 585-614.

Bottema, M.J.M. and S.R. Bush (2012), ‘The durability of private sector-led marine conservation: a case study of two entrepreneurial marine protected areas in Indonesia', Ocean and Coastal Management, 61 (June), 38-48.

Bush, S.R., B. Belton, D. Hall, P. Vandergeest, F.J. Murray, S. Ponte et al. (2013), 'Certify sustainable aquaculture?’, Science, 341 (6150), 1067-8.

Bush, S.R., M. Bottema, J.J. Midavaine and E. Carter (2017), 'Sustainability entrepreneurship in marine protected areas’, in K. Nicolopoulou, M. Karatas- 
Ozkan, F. Janssen and J. Jermier (eds), Sustainable Entrepreneurship and Social Innovation, New York, Routledge, 124-140.

Carroll, A.B. and K.M. Shabana (2010), 'The business case for corporate social responsibility: a review of concepts, research and practice', International Journal of Management Reviews, 12 (1), 85-105.

Cashore, B., G. Auld, S. Bernstein and C. McDermott (2007), 'Can non-state governance 'ratchet up' global environmental standards? Lessons from the forest sector', RECIEL, 16 (2), 158-72.

Caswell, J.A. (1998), 'Valuing the benefits and costs of improved food safety and nutrition', Journal of Agricultural and Resource Economics, 42 (4), 409-24.

Christie, P. and A.T. White (2007), 'Best practices for improved governance of coral reef marine protected area', Coral Reefs, 26 (4), 1047-56.

Chuenpagdee, R., J.J. Pascual-Fernandez, E. Szelianszky, J.L. Alegret, J. Fraga and S. Jentoft (2013), 'Marine protected areas: re-thinking their inception', Marine Policy, 39, 234-40.

Coff, C., D. Barling, M. Korthals, and T. Nielsen (eds) (2008), Ethical Traceability and Communicating Food, Berlin: Springer.

Colwell, S. (1997), 'Entrepreneurial marine protected areas: small-scale, commercially supported coral reef protected areas', in M.E. Hatziolos, A.J. Hooten and M. Fodor (eds), Coral Reefs: Challenges and Opportunities for Sustainable Management, Washington, D.C: World Bank, pp. 110-14.

Colwell, S. (1998), 'Dive-tourism and private stewardship of small-scale coral reef marine protected areas’, in I. Dight, R. Kenchington and J. Baldwin (eds), Proceedings: International Tropical Marine Ecosystems Management Symposium 
(ITMEMS), Townsville, Queensland: Great Barrier Reef Marine Park Authority, pp. 217-21.

De Groot, J. and S.R. Bush (2010), 'The potential for dive tourism led entrepreneurial marine protected areas in Curacao’, Marine Policy, 34 (5), 1051-9.

Dixon, J.A., L. Fallon Scura and T. Van ’t Hof (1993), 'Meeting ecological and economic goals: marine parks in the Caribbean’, Ambio, 22 (2-3), 117-25.

Donnelly, K.A.-M. and P. Olsen (2012), 'Catch to landing traceability and the effects of implementation - a case study from the Norwegian white fish sector', Food Control, 27 (1), 228-33.

Fiorillo, J. (2014), ‘Wegmans using traceability to build its seafood business’, accessed 17 September 2015 at http: //seafoodinternationaldigital.com/wegmans-usingtraceability-to-build-its-seafood-business/.

Foley, P. (2012), ‘The political economy of Marine Stewardship Council certification: processors and access in Newfoundland and Labrador's inshore shrimp industry', Journal of Agrarian Change, 12 (2-3), 436-57.

Foley, P. (2013), 'National government responses to Marine Stewardship Council (MSC) fisheries certification: insights from Atlantic Canada’, New Political Economy, 18 (2), 284-307.

Foley, P. and K. Hébert (2013), 'Alternative regimes of transnational environmental certification: governance, marketization, and place in Alaska’s salmon fisheries', Environment and Planning A, 45 (11), 2734-51.

Folke, C., T. Hahn, P. Olsson and J. Norberg (2005), ‘Adaptive governance of socialecological systems', Annual Review of Environment and Resources, 30, 441-73. 
Galaz, V., B. Crona, H. Österblom, P. Olsson and C. Folke (2012), 'Polycentric systems and interacting planetary boundaries - emerging governance of climate changeocean acidification-marine biodiversity', Ecological Economics, 81 (September), $21-32$

Gale, F. and M. Haward (2011), Global Commodity Governance: State Responses to Sustainable Forest and Fisheries Certification, London: Palgrave Macmillan.

Gulbrandsen, L.H. (2009), 'The emergence and effectiveness of the Marine Stewardship Council’. Marine Policy, 33 (4), 654-60.

Gulbrandsen, L.H. (2014), 'Dynamic governance interactions: evolutionary effects of state responses to non-state certification programs’, Regulation and Governance, 8 (1), 74-92.

Ha, T.T.T. and S.R. Bush (2010), 'Transformations of Vietnamese shrimp aquaculture policy: empirical evidence from Ca Mau province, the Mekong delta’, Environment and Planning C: Government and Policy, 28 (6), 1101-19.

Hartmann, P. and V. Apaolaza-Ibáñez (2012), ‘Consumer attitude and purchase intention toward green energy brands: the roles of psychological benefits and environmental concern', Journal of Business Research, 65 (9), 1254-63.

Hatanaka, M., C. Bain and L. Busch (2005), 'Third-party certification in the global agrifood system', Food Policy, 30 (3), 354-69.

Iles, A. (2004), 'Making seafood sustainable: merging consumption and citizenship in the United States’, Science and Public Policy, 31 (2), 127-38.

Jacquet, J.L. and D. Pauly (2008), ‘Trade secrets: renaming and mislabeling of seafood', Marine Policy, 32 (3), 309-18. 
Jacquet, J., J. Hocevar, S. Lai, P. Majluf, N. Pelletier, T. Pitcher et al. (2010), 'Conserving wild fish in a sea of market-based efforts', Oryx, 44 (1), 45-56.

Kearney, R., G. Farebrother, C.D. Buxton and P. Goodsell (2013), 'How terrestrial management concepts have led to unrealistic expectations of marine protected areas’, Marine Policy, 38 (March), 304-11.

Konefal, J. (2013), ‘Environmental movements, market-based approaches, and neoliberalization: a case study of the sustainable seafood movement', Organization \& Environment, 26 (3), 336-52.

Mascia, M.B., C. Claus and R. Naidoo (2010), 'Impacts of marine protected areas on fishing communities', Conservation Biology, 24 (5), 1424-9.

McKenna, J., A.T. Williams and J.A.G. Cooper (2011), 'Blue flag or red herring: do beach awards encourage the public to visit beaches?', Tourism Management, 32 (3), 576-88.

Midavaine, J.J. (2014), 'Co-management and entrepreneurship: an analysis of the relation between co-management and the opportunities for commercial entities to invest in biodiversity conservation in Belize’s marine protected areas', MSc thesis, Social Sciences Group, Wageningen University, Wageningen.

Miller, A. (2014), 'Governance innovation networks for sustainable tuna’, PhD thesis, Wageningen University, Wageningen.

Miller, A.M.M., S.R. Bush and P.A.M. van Zwieten (2014), 'Sub-regionalisation of fisheries governance: the case of the Western and Central Pacific Ocean tuna fisheries’, Maritime Studies, 13 (1), 1-20.

Mol, A.P. (2015), ‘Transparency and value chain sustainability', Journal of Cleaner Production, 107 (November), 154-61. 
Moody Marine Limited (2011), 'MSC assessment report for PNA Western and Central Pacific skipjack tuna (Katsuwonus pelamis) unassociated and log set purse seine fishery’, Version 5 Public Certification Report, Derby.

Nadvi, K. and F. Wältring (2002), 'Making sense of global standards', INEF report, issue 58/2002, Gerhard-Mercator-Universität Duisburg, accessed 21 October 2016 at http://edoc.vifapol.de/opus/volltexte/2013/4549/pdf/report58.pdf.

National Ocean and Atmospheric Administration (NOAA) (2015), Presidential Task Force on Combating IUU Fishing and Seafood Fraud: Action Plan for Implementing the Task Force Recommendations. Washington, DC: National Ocean and Atmospheric Administration, accessed 5 October 2015 at http://www.nmfs.noaa.gov/ia/iuu/noaa_taskforce_report_final.pdf.

Ostrom, E. (2010), 'Beyond markets and states: polycentric governance of complex economic systems’, American Economic Review, 100 (3), 641-72.

Parkes, G., J.A. Young, S.F. Walmsley, R. Abel, J. Harman, P. Horvat et al. (2010), 'Behind the signs: a global review of fish sustainability information schemes', Reviews in Fisheries Science, 18 (4), 344-56.

Peattie, K. (2010), ‘Green consumption: behavior and norms’, Annual Review of Environment and Resources, 35 (1), 195-228.

Perman, R., Y. Ma, M. Common, D. Maddison and J. McGilvray (2011), Natural Resource and Environmental Economics, 4th edn, Harlow: Pearson.

Ponte, S. (2008), 'Greener than thou: the political economy of fish ecolabeling and its local manifestations in South Africa’, World Development, 36 (1), 159-75. 
Riedmiller, S. and E. Carter (2001), 'The political challenge of private sector management of marine protected areas: the Chumbe Island case, Tanzania’, ACPEU Fisheries Research Report 10, 141-53.

Rife, A.N., B. Erisman, A. Sanchez and O. Aburto-Oropeza (2013), 'When good intentions are not enough ... insights on networks of "paper park” marine protected areas', Conservation Letters, 6 (3), 200-212.

Roff, J.C. (2014), 'Networks of marine protected areas - the demonstrability dilemma’, Aquatic Conservation: Marine and Freshwater Ecosystems, 24 (1), 1-4.

Selig, E.R. and J.F. Bruno (2010), ‘A global analysis of the effectiveness of marine protected areas in preventing coral loss', PLoS ONE, 5 (2), e9278.

Svensson, P., L.D. Rodwell and M.J. Attrill (2010), 'The perceptions of local fishermen towards a hotel managed marine reserve in Vietnam', Ocean and Coastal Management, 53 (3), 114-22.

Symes, D. (2006), 'Fisheries governance: a coming of age for fisheries social science?', Fisheries Research, 81 (2-3), 113-17.

Tamm Hallström, K. and M. Boström (2010), Transnational Multi-stakeholder Standardization: Organizing Fragile Non-state Authority, Cheltenham, Uk and Northampton, MA, USA: Edward Elgar.

Teh, L.C.L., L.S.L. Teh and F.C. Chung (2008), ‘A private management approach to coral reef conservation in Sabah, Malaysia', Biodiversity and Conservation, 17 (13), 3061-77.

Tietenberg, T. and L. Lewis (2012), Environmental \& Natural Resource Economics, Upper Saddle River, NJ: Pearson. 
Tongson, E. and M. Dygico (2004), 'User fee system for marine ecotourism: the Tubbataha Reef experience’, Coastal Management, 32 (1), 17-23.

United Nations (2015), Transforming Our World: The 2030 Agenda for Sustainable Development, New York: United Nations.

Van den Burg, S.W.K., A.P.J. Mol and G. Spaargaren (2003), ‘Consumer-oriented monitoring and environmental reform', Environment and Planning C: Government and Policy, 21 (3), 371-88.

Vandergeest, P. (2007), 'Certification and communities: alternatives for regulating the environmental and social impacts of shrimp farming', World Development, 35 (7), $1152-71$.

Vandergeest, P. and A. Unno (2012), ‘A new extraterritoriality? Aquaculture certification, sovereignty, and empire’, Political Geography, 31, 358-67.

Vellema, S. and J. van Wijk (2015), 'Partnerships intervening in global food chains: the emergence of co-creation in standard-setting and certification', Journal of Cleaner Production, 107 (November), 105-13.

Wessels, C.R. (2002), 'The economics of information: markets for seafood attributes’, Marine Resource Economics, 17 (2), 153-62.

White, A.T., P.M. Aliño, A. Cros, N.A. Fatan, A.L. Green, S.J. Teoh et al. (2014), 'Marine protected areas in the Coral Triangle: progress, issues, and options', Coastal Management, 42 (2), 87-106. 